\title{
Thoughts on Integrating Innovation and Entrepreneurship Education into the Whole Process of Talent Training
}

\author{
Wang Qingjun \\ Economics and Management Institute \\ Shenyang Aerospace University \\ Shenyang City, China \\ 32582669@qq.com
}

\author{
Wu Jingtai \\ Economics and Management Institute \\ Shenyang Aerospace University \\ Shenyang City, China
}

\begin{abstract}
The employment prospects of graduates in China instill little optimism so far, and the employment pressure increases year by year, which undoubtedly brings a lot of pressure to the country, universities and individual students. In such a situation, in order to find a way out, it is necessary to fuse innovation and entrepreneurship education into the whole process of talent training. Only in this way can the purpose of innovation and entrepreneurship education of higher educational institutions to change students' employment ideas be achieved in a better way. At the same time, students' innovation and entrepreneurial ability can be cultivated and improved. Thus, not only students' comprehensive ability and quality are improved, but also the employment pressure is relieved to some extent by encouraging entrepreneurial actions, which is of great practical significance.
\end{abstract}

Keywords-innovation and entrepreneurship education, employment pressure, talent training

\section{INTRODUCTION}

Innovation and entrepreneurship education aims to cultivate the talents of comprehensive quality who are equipped with innovation and entrepreneurial ability, which are closely related. Based on the current situation of Chinese higher education institutes, as well as the developing goal of the future, Chinese Ministry of Education combined the innovation and entrepreneurship closely and further came up with the expression namely innovation and entrepreneurship education, which can be regarded as one with great value of guiding the development. Compared with the widespread entrepreneurship activities, the innovation and entrepreneurship activity is characterized with its own feature, which focuses on cultivating the innovative talents. Through several years of professional education, the university students have processed the potential to innovate or engage in the entrepreneurship activity. However, this kind of potential needs to be developed to be further released which needs the innovation and entrepreneurship education to trigger. Innovation and entrepreneurship education can help the mass students to realize the goal of getting a job or starting their own businesses, which has great significance and value to the nation, the university as well as the individuals.
Through several years of exploration and development, the innovation and entrepreneurship education is gradually becoming an important way to cultivate the innovative and entrepreneurial talent, and this pattern of education is gradually accepted by people. But the assessment towards this pattern of education tends to be utility-oriented, which makes our innovation and entrepreneurship education still limited in entrepreneurship activities either regarding from its essence or its nature, with a comparatively weak development. Based on current situation, we have to reexamine and relocate our innovation and entrepreneurship education both from its essence and its nature, and we have to integrate it in the whole process of the talent cultivation, change its utility-oriented assessment gradually, realize the non-utility goal, and thus promote the scientific development of innovation and entrepreneurship education in a more effective way.

\section{SET UP A NEW CONCEPT ON INNOVATION AND}

\section{ENTREPRENEURSHIP EDUCATION}

Nowadays, the higher education in China is mainly oriented by the specialized education, the implementation of which is based on a particular specialized talent training program, and there are diverse curriculum systems supporting this training program. Therefore it is certainly not easy to help innovation and entrepreneurship education merge into the whole process of talent cultivation by simply adding several innovation and entrepreneurship related courses. What we need to do is to integrate the innovation and entrepreneurship education into every part of the entire talent training program. Based on the traditional specialized education, we should transfer and update the ideas and concepts of education, and deepen reform in the pattern of talent cultivation, education and teaching. We also need to pay more attention to the development of the awareness, spirit and skills of entrepreneurship while emphasizing the training of students' professional knowledge and skills in order to turn out the comprehensive talented personnel which meet the need of the society.

At present, the curriculum system in our professional talent cultivation is mainly composed by the public elementary course, the professional course, the public 
elective course, and various kinds of practice, training, course design, graduation project and etc. And the public elementary mainly refers to the course of basic knowledge which includes both natural and social sciences, while the professional course mainly includes the professional basic course, the professional core course, the professional limited optional course and etc, and the public elective course mainly refers to the course of comprehensive quality and ability. The professional course aims to cultivate the professional knowledge, ability and quality, while the public basic course and public elective course takes the comprehensive quality education as the base, and the practice, training, the course design and the graduation project is a platform to apply the knowledge learned to practice. Regarding the constitution of the curriculum system in the pattern of specialized talent training, we can clearly see that the innovation and entrepreneurship education is not split from the specialized education and they should be an organic unity. The professional knowledge, skills, comprehensive ability, quality and the training of practical ability supplied by the professional education are necessary for the innovation and entrepreneurship education, serving as its base, and the professional education provides the foundation for the cultivation of innovation and entrepreneurship talent. Theretofore it is an important aspect of innovation and entrepreneurship education [1].

However, the current situation is still not ideal. As the concept of innovation and entrepreneurship education was only put forward recently, and most teachers in universities and colleges still lack the deep recognition and practice of this. Many of these teachers still stay in the lower level of their cognitive stage, they still teach only for teaching. It is therefore difficult to make students active and constructive with this dated teaching concept, content and method not updated or developed. Let alone awakening their awareness and thinking in innovation and entrepreneurship. Some teachers may even keep a single teaching plan or lecture from the start to the end of their career, so how can we count on them to cultivate talents with innovative and entrepreneurial spirit. Therefore the first step to combine innovation and entrepreneurship education into the whole process of talent training, we need the transfer of the faculty themselves. They should apply the concept of innovation and entrepreneurship education into their own teaching thinking, content and method, actively explore the innovative and entrepreneurial elements in the talent training program, advance with the time, keep exploring to seek good methods to initiate students' enthusiasm in study, awaken their awareness and thinking of innovation and entrepreneurship, equip them with related knowledge, quality and ability, as well as awareness and ability to find out and solve out the problems, and lay a solid foundation of professional knowledge which can play a great role in future innovation and entrepreneurship. Only when teachers have applied the concept of innovation and entrepreneurship education into every part of education and teaching, can innovation and entrepreneurship education actually integrate into the whole process of talent cultivation ${ }^{[1,2] \text {. }}$

\section{CurRent Situation OF InNOVATION AND \\ ENTREPRENEURSHIP EDUCATION}

The key element of successful entrepreneurship is the awareness of entrepreneurship, as it is a desire which can motivate people to start his own business, and it is also an inner driving force for Entrepreneurship. Facing a harsh employment situation, how many students have taken it seriously to start their businesses? We did a survey among forty graduates on this question, and the result turned out that about $60 \%$ students have never considered entrepreneurship, $30 \%$ students claimed that they once had an idea of entrepreneurship, while $10 \%$ students claimed that they would put into practice under mature situation. Confronting such a result, few of us have considered what had caused this. Actually, examination-oriented education has been overwhelmingly dominant in our country. Though quality-oriented education has been advocated for several years in China, there still is little improvement in the system and pattern of the education. Consequently the concept of quality-oriented education failed to be carried on thoroughly, and the long-term of examination-oriented education cast a profound influence in our students - the students are in a serious lack of innovation and entrepreneurship awareness. As is well known, the examination-oriented education, with the dated pattern and a single method, adopts unified teaching plan and cultivating program in teaching the students of one major, restrains students' individuality. The teachers concentrate only on one specialized aspect of knowledge, which will cause narrow range of knowledge and the lack of humanistic knowledge, and the students are not able to choose the content of study according to their actual needs [3].

The first step to effectively implement the innovation and entrepreneurship education is to transfer the concept of employment. Numerous students used to regard employment as finding a job. This kind of concept will definitely leads to passive employment, while the innovation and entrepreneurship education is a kind of education which promotes the passive concept of employment to transfer into an active one. At present, innovation and entrepreneurship education has occupied a position in global education which is equal with the academic education and vocational education. This also reflects the need and trend in modern development and educational reform. To implement the innovation and entrepreneurship education in colleges and universities, we must base this on various qualities, knowledge and ability needed in innovation and entrepreneurship, reform the traditional training pattern and carry on the concept of innovation and entrepreneurship education into every part of the education to cultivate the students' awareness of innovation and entrepreneurship, and strengthen their quality and ability for innovation and entrepreneurship. We should encourage students to change their old concept about employment, take entrepreneurship as one option in their employment, and combine their own professional skills and interest to eventually realize their expected self-value and social value. 


\section{IMPLEMENTATION OF INNOVATION AND ENTREPRENEURSHIP EDUCATION INTO THE SYSTEM OF TALENT TRAINING.}

The innovation and entrepreneurship education now has been a focus in the entire society as well as the whole world. This is not just a most effective way to ease nowadays employment pressure, is also a trend of the time pushing the talent to improve. Whether the innovation and entrepreneurship education can be implemented effectively will have direct impact on our nation's educational quality and the quality of the talents cultivated. We can regard this as a matter which functions as the key of building a sound talent system and the realization of sustainable economic growth. Therefore, it is extremely pivotal to integrate the innovation and entrepreneurship education into the whole process of talent training. The following are three basic guiding methods:

\section{A. Take educating people as the goal, and scientifically position the innovation and entrepreneurship education in colleges and universities}

Innovation and entrepreneurship education in essence is just a kind of quality-oriented education with a core of educating people. Therefore, when carrying on the innovation and entrepreneurship education, we should insist on the scientific development outlook of putting people first, start from students' development, and take it as a goal to cultivate and improve their comprehensive quality as well as their ability, free them from the limitation of examination-oriented education and help them obtain an overall development. Innovation and entrepreneurship education, aiming at educating people means to integrate itself into the quality-oriented education, permeate in the whole process of educating people, and then develop this kind of education in students widely. Through this kind of educational pattern, we can further deepen the quality-oriented education, awaken and cultivate students' awareness of innovation, and improve their comprehensive quality at the same time [4].

\section{B. Centering on teaching, build an innovation and entrepreneurship education curriculum system with multidisciplinary support}

On innovation and entrepreneurship education itself, it is a teaching-centered education system, so to better implement such education, a good innovation and entrepreneurship education curriculum system should first be established, which means fully exerting the main function of classroom teaching. Besides, innovation and entrepreneurship education is a comprehensive discipline involving many other disciplines, so it requires interdisciplinary curriculum design and settings. To better fusing innovation and entrepreneurship education into the whole process of talent training, a curriculum system of such education must be established and kept sound, to fuse the educational concept fit for the development of times and meeting the needs of educational reform into each step of education and teaching. Meanwhile, emphasis should be laid on the complementary relation among disciplines and the comprehensiveness of teaching content. Related knowledge such as management and economics should also be introduced, to form a practical, scientific and reasonable curriculum system for innovation and entrepreneurship education covering a wide scope of knowledge.

There must be a strong faculty to support the establishment of the curriculum system for innovation and entrepreneurship education. When a faculty for the innovation and entrepreneurship education is set up, it is necessary to cultivate both the theoretical and the practical types of teaching staff. In the cultivation of theoretical teaching staff, attention should be paid to the cultivation of teachers' innovative thinking, for only in this way can the teachers play a role of spiritual model in teaching students; in the construction of practical faculty teams, more emphasis should be laid on the practical experience of teachers, so generally those with excellent entrepreneurial experience or those who have worked or are still working in enterprises will be employed as teachers of innovation and entrepreneurship education, who have both management and teaching abilities. In addition to teachers, teaching materials and methods are an important part of the curriculum system. To improve teaching materials and methods, the research on innovation and entrepreneurship education must be strengthened. Therefore, the following work should be done properly: guide teachers in taking initiative to study innovation and entrepreneurship education; in combination with the educational features of each area, develop teaching materials for such education, and find out proper and effective teaching methods; lead students to study independently in multiple ways, and achieve actual effects through practical training; finally, the integrated quality and ability of students can be improved consciously $[4,5]$.

\section{Based on services, expand the practice platform for innovative and entrepreneurial talents}

Innovation and entrepreneurship education is rather practical, so therefore must be a corresponding practice service platform, which can help entrepreneurial students accumulate experience, improve ability and build character and willpower. The extension of such a service platform is generally composed of the construction of the two platforms in and out campus.

The extension of innovation and entrepreneurial education service platform is generally carried out in the following three ways: First, through combining innovation and entrepreneurship education with social practice and practice courses and through internships, graduation design and a variety of innovation and entrepreneurial competitions, their integration with such education is realized. Second, establish student entrepreneurship parks. Through such a base, necessary instruction and corresponding site, fund and equipment support can be provided to individual students and groups in entrepreneurial practices. Third, establish entrepreneurial service websites. Such a platform can provide a convenient information communication channel for entrepreneurs, who can keep abreast of entrepreneurial trends and business opportunities, and directly ask questions on some government policies. Thus, the communication, interchange and delivery of information can be very easy and convenient.

The extension of the innovation and entrepreneurship education service platform out of campus is mainly to increase the opportunities for students to come into 
contact with the society and train themselves through the integration of social resources and channel extension and employment and entrepreneurial bases enrolling college students, thus let students improve their own abilities. The support from social systems is rather important for college innovation and entrepreneurship education, so the relation between colleges and enterprises must be reinforced, to provide students with more social practice opportunities. The students can practically learn about enterprises and their operation principles, and can learn about and study these things and train and improve themselves in real social environment. In addition, the society is the best practice platform. The government should help some students with entrepreneurial intentions use their spare time or vacations to try entering the society, to establish and participate in some entrepreneurial projects with few risks and little investment, on the premise of not influencing their own studies. This can help them grow better and faster [6].

\section{CONCLUSION}

To sum up, along with the increase of social employment pressure year by year, innovation and entrepreneurship education has gradually become an important reform of teaching in China's college education, as well as an important part of college education. The ultimate goal of innovation and entrepreneurship education is not to make every student establish his or her own enterprise, but to enable them to change traditional and old employment ideas, as well as to improve their own entrepreneurial consciousness and ability. In this way, the students can have entrepreneurial consciousness and courage and successfully establish their own businesses.

\section{ACKNOWLEDGMENT}

The work is supported by Teaching reform project of Liaoning Province Education Department (UPRP20140202).

\section{REFERENCES}

[1] Tang Chenghua, Ye Yi. Analysis on the "One Body with Two Wings" Entrepreneurial Talents Cultivation Path of Digital Publishing [J]. Innovation and Entrepreneurship Education, 2012 (4): 17-19.

[2] Wang Guangjie, Zhang Yuxia, Wang Aiqin. Introduce Entrepreneurship Concept into Higher Vocational Education [J]. Vocational Education Forum, 2005, (8).

[3] He Shengyu, Zhu Ping, Liu Chenghua, et al. Establish the Concept of CDIO Engineering Education, and Cultivate Creative Talents of E-Commerce [J]. Innovation and Entrepreneurship Education, 2012 (4): 3-5.

[4] Luan Yongbin, Yu Xiuzhi. Problems in Higher Vocational College Students' Entrepreneurship Education and Countermeasures $[\mathrm{J}]$. Vocational Education, 2008, (5): 52-54.

[5] Gong Ruxun, Xue Xuejun, Li Xinsheng. Practice and Exploration of Implementing Entrepreneurship Education of Higher Vocational Students [J]. China Vocational Technical Education, 2007, (13).

[6] Yang Chenguang. Entrepreneurship Education: How to Guide College Students [N]. China Education Daily, 2008-11-18. 